Linguistik Terapan 14 (2) (2017): 194-203

Jurnal Linguistik Terapan Pascasarjana

Available online

http://jurnal.unimed.ac.id/2014/index.php/JLT-Unimed

\title{
PROCESS AS A TRANSITIVITY ELEMENT
}

\author{
IN CLASSROOM DISCOURSE
}

\author{
Y U N I A R \\ T. Silvana Sinar \\ Busmin Gurning \\ Linguistik Terapan Bahasa Inggris
}

Diterima Agustus 2017; Disetujui oktober 2017; Dipublikasikan Desember 2017

\begin{abstract}
The purposes of the study is to describe about the experiential realization through transitivity analysis in classroom discourse, and only concerns with one component of the metafunctions that is the experiential meaning. The problem investigated in this study are (1) The transitivity processes used by the teachers in English classroom context; (2) the description of processes realized by teachers in the classroom context; and (3) the field of discourse in which the processes are realized in the classroom context. This study is data -based with descriptive qualitative and quantitative in nature and the method is observational. The location of the sudy were in 2 schools, and the subjects of the study are 3 English teachers from both schools in Aceh tamiang 2016. In collecting the data, this study is used a means of audio-visual recording and transcriptions, and analyzed by employing Interactive Model. The result of the study from data analysis with total of clauses produced by 3 teachers each two sessions are 2175 clauses. It gained 726 clauses of Material Process (33.38\%), followed by behavioural process gained 425 clauses (19.54\%), relational process gained 296 clauses $(13.60 \%)$, existantial process gained 287 clauses $(13.19 \%)$, mental process gained 250 clauses $(11.49 \%)$, and verbal process gained 191 clauses $(8.78 \%)$.
\end{abstract}

Keywords: Classroom Discourse, Process of Transitivity, Systemic Functional Linguistic

\section{Theory}


How to Cite: Yuniar (2017).

Process as a Transitivity Element in Classroom Discourse. Jurnal Linguistik Terapan Pascasarjana Unimed, 14 (2): 194-203.

ISSN 2407-7410

\section{INTRODUCTION}

People use language to communicate, express ideas, carry on arguments, convey information from one person to another or even to entertain. The communication takes place through speech, writing or sign language. The ways to express the speech, writing and sign are by choosing functions in the transitivity system of the language. The transitivity is expressed through choices of verbs that realizing one's speech and writing that are expressed through grammar. Furthermore, the transitivity also covers sign language that expressed through the transitivity of expression body language, mimic, gestures, etc.

Halliday $(1985,1994,2004,2014)$, however, found the new concept of transitivity. The new transitivity concept represents a further development of the old concept. It is the experiential function of clause that one produce, or the structure of clauses. Transitivity system is one the analytical systems that explain about process participant and circumstance as the realization of people produces language.

There are three components of what Halliday calls a "transitivity process", namely:

a. The process itself,

b. Participants in the process; and

c. Circumstances associated with the process.(Eggins, 2004:57).

According to the latest edition of Halliday's (2014) An Introduction to Functional Grammar, he devides the transitivity system is composed of six processes that represent human experience in terms of: physical and physiological actions (Material and Behavioral), thinking and speaking actions (Mental and Verbal) and actions that signal the existence of something/someone and their identifying features (Existential and Relational).

Relating to this system, Law of the Republic of Indonesia, No. 14 Year 2005 on teachers and lecturers, is explained that teachers have four required pedagogic, professional, social, and personality competencies in running the professional task. Social competence, is the ability of teachers to communicate interact effectively and efficiently with students,fellow teachers, students' parents, and surrounding communities. Good teacher with good social competency will lead to the sudents successfullness, school and enhance the national education quality.

A classroom is a learning space where learning can take place uninterrupted by outside distractions. In the classroom there are many things, teacher and student, equipments which are needed to facilitate the teaching learning activities and of course there must be discourse. 
Discourse is a text, sentence, clause that can be performed in speech, conversation or even composition which belong to teachers' utterences in the class. Discourseis a categorythatbelongstoandderivesfromthesocialdomain, and text is a category that belongs to derives from the linguistic domain. The relationbetween thetwo isoneofrealization: Discoursefindsitsexpressionin text. However, this is never a straightforward relation; any one text may be the expression or realization of anumber of sometimescompetingand contradictory discourses".(Emphases added) (Kress 1985, in Sinr 2007:23).

Classroom discourse is a process of teaching and learning in classroom that needs a language to communicate the information from teacher to the students.In classroom, an interaction is an essential part of teaching learning process between teacher and students. Interaction has been defined as aprocess whereby two or more people engaged in reciprocal actions. In accordance to the classroom discourse, different teacher is assumed as having different way in transferring the information. Even the same teacher in different class use different way of communication. It is interested to analyze the process of interaction between teacher and students through the use

In the reality, many teachers have been criticized by many society. The students are assigned to translate difficult phrases and to have the grammar notes with terms that are not understood. Sikki, 2013). It means that the classroom activities and teachers' expression do not facilitate students to learn and speak English well. In other words the experiential verbs in the system of transitivity made by the teacher are not clear produced and make students confuse so that it effects in the communication. For example:

a. " I'm waiting for you to be quite", this clauses should be "I wait for you to be quite'. "waiting" is mental process verb that can not be using in progressive.

b. "We won't start until everyone is quite" should be "If you aren't quite, I shan't begin the lesson". The first clause is material process while actually it is mental process

c. "Pay attantion every body" should be "Attention, please". In this case the experiential meaning actually relates to mental process that impute consciousness to non sensate beings. It is a phenomenon which is sensed: felt, thought or seen.

d. "Settle down now so we can start" should be" please be on your seat, we begin to study ". The speaker actually would like to express the participants do something, material process, but the choice is mental process

e. "Turn to page.." should be "let's move on to the page..." The idea is material process but the choice is mental process.

Teachers and students interaction in the classroom faced many problems when they are informing, conveying, announcing the information to the students. They try to use and choose of experiential processes which are needed in delivering the subject matter. Seing the examples above, they can minimize the wrong choice of experiential processes by understanding and implementing the system of transitivity. 
The transitivity system can analyze clauses effectively, and also the system can solve the problem of reference personal in contexts of potential ambiguity. This condition make this research becomes important and need to be analyzed. Based on the background there are some problems that will be analyzed, and these problems need tobe resolved. The problems are:

a. What kinds of transitivity processes are used by teachers in classroom discourse?

b. How are the proceses realized by the teachers in classroom discourse?

c. Why are the processes realized in the classroom discourse in the ways they are ?

The study is focused on the process as an element of Transitivity found in classroom discourse which are realized by 3 teachers of 2 senior High school. The class to be studied in each school is one of English where the medium of instructions are both (interchangeable) English and Bahasa Indonesia (BI).

Theoretically, the findings deal with the two aspects, first, about the transitivity realized in spoken academic classroom discourse. Second, investigating classroom discourse phenomena. This being the case, whatever this study has achieved may contribute to the enrichment of classroom discourse studies in general and become the references for further studies, related to Classroom Discourse.

Practically the findings deal with discourse, languageteacher couldhave anadequateknowledgeonexperientialmeaning and able to apply that in process of teaching. Moreover,It can be useful as one of the references inanalyzingprocess inclassroom interaction and alsotofindoutthesixtypesof experientialmeaningprocessinclassroom discourse.Hopefully, this will beusefulforthereaderswhoareinterestedinstudyingdiscourseanalysiswith focusonexperientialmeaningprocess.

\section{RESEARCH METHODOLOGY}

The qualitative are used to enforcement the transivity process in classroom discourse. This research employed a case study. A case study refers to the study done to a subject, a setting, or a depository of data (Bogdan and Biklen, 1992:68).This research used observational design, whereas the analysis model used the inductive type which started from the data or facts obtained in the field for abstraction and drawing the conclusion. The three English teachers and their utterances are the source of data for this research. Bogdan and Biklen (2003) announce that official, personal and public documents. The observation data was taken by the following procedure:

a. Preparing for conducting the research such as preparing the tools needed such as video tape recorder, note book, etc, and approaching the subjects.

b. The utterances uttered by three different subjects in different situation were observed and audiovisually and simultaneously tape, to obatain the data. Video tape was settled in the best position to record the classroom interaction, mean while the researcher sat at the back of the classroom to 
take back up notes on the situation in the classroom and students' responses which are otherwise not record in camera.

c. Transcribing the recording data.

\section{FINDINGS AND DISCUSSIONS}

The participants were three English teachers from SMAN 1 Kejuruan Muda with 10 years of teaching English experiences and two teachers fromSMAN 2 Kejuruan Muda with 16 and 15 years' experience in teaching English.Each of them had two teaching sessions. All the sessions were recorded and transcript. The transcripts were splatted into clauses which divided into two groups: teacher and students. Each clause then was analyzed to identify the process used in the clause, which included the participants and the circumstances. The following tableshows the result of data analyzing of

transitivity

process

released

by

them.

Table 1

Proportion of Process Type Used by Teacher

\begin{tabular}{|c|c|c|c|c|c|c|c|c|c|c|c|c|c|}
\hline \multirow{3}{*}{$\begin{array}{l}\mathbf{N} \\
\mathbf{0}\end{array}$} & \multirow{3}{*}{$\begin{array}{l}\text { Types of } \\
\text { Process }\end{array}$} & \multicolumn{9}{|c|}{ Teacher } & \multirow{3}{*}{ Total } & \multirow{3}{*}{$\%$} & \multirow{3}{*}{$\mathbf{R}^{* *}$} \\
\hline & & \multicolumn{3}{|c|}{1} & \multicolumn{3}{|c|}{2} & \multicolumn{3}{|c|}{3} & & & \\
\hline & & $\mathbf{N}^{*}$ & $\%$ & $\mathbf{R}^{* * *}$ & $\mathbf{N}^{*}$ & $\%$ & $\mathbf{R}^{* * *}$ & $\mathbf{N}^{*}$ & $\%$ & $\mathbf{R}^{* * *}$ & & & \\
\hline 1 & Material Process & 339 & 46.69 & I & 258 & 35.53 & I & 129 & 17.76 & I & 726 & 33.38 & 1 \\
\hline 2 & $\begin{array}{l}\text { Relational } \\
\text { Process }\end{array}$ & 93 & 31.41 & IV & 118 & 39.86 & II & 85 & 28.71 & III & 296 & 13.61 & 3 \\
\hline 3 & $\begin{array}{l}\text { Behavioral } \\
\text { Process }\end{array}$ & 213 & 50.12 & II & 111 & 26.12 & III & 101 & 23.76 & II & 425 & 19.54 & 2 \\
\hline 4 & Verbal Process & 57 & 29.84 & $\mathrm{~V}$ & 53 & 27.75 & VI & 81 & 42.41 & IV & 191 & 8.78 & 6 \\
\hline 5 & Mental Process & 93 & 37.2 & IV & 82 & 32.8 & IV & 75 & 30 & $\mathrm{~V}$ & 250 & 11.49 & 5 \\
\hline 6 & $\begin{array}{l}\text { Existential } \\
\text { Process }\end{array}$ & 153 & 53.31 & III & 65 & 22.65 & V & 69 & 24.04 & VI & 287 & 13.20 & 4 \\
\hline 7 & $\begin{array}{l}\text { Meteorological } \\
\text { Process }\end{array}$ & 0 & & & 0 & & & 0 & & & 0 & - & 7 \\
\hline & Total & 948 & 43.59 & & 687 & 31.57 & & 540 & 24.83 & & 2,175 & $100 \%$ & \\
\hline
\end{tabular}


Based on the table above we can say that:

The Material Process type occures dominantly from all three teachers . they realized 726 times of material process and 543 times of material process realized by Teachers were creative material processas to give order students to do something. The second majority process realized by all teachers was Behavioral process. There were 425 times of behavioral process realized by the teachers. The process mainly containing the notions of taking attention to what the teachers ordered to do.

The third process realized by teachers was relational process. Relational process involves states of being, including having. The relational process was realized for 296 times and 145 out of relational process realized were attributive mode.

The fourth process occuring most was Existential process. It represents that something exists or happens. There were 287 times realization produced by all the teachers. The fifth process was mental process, while The cognitive mental process was the most dominant sub-type occurerence. It was realized 250 times. The sixth was verbal process. There were 191 times verbal process was realized in this research.The three teachers varies in the used of process. Whereas teacher 1 and 3 share similar the most frequently occurence was material Process, the second one was Behavioral process, while teacher 2 has her own charecteristic with relational process as the second one.

The analysis of the situation in the classroom stated above, It indicates that the first dominant process realized by teachers is Material process which implied that the role of teachers in classroom teaching and learning process were to direct the students to learn from one activity to another. Behavioural process were realized when the teachers directing students to use their sensing of seeing and listening. The third occurences process which was done by the teachers was relational process. Mostly it indicated that the teachers would like to to assign quality rather than establish the identity.

The fourth process most prominently occured was existantial process. This realized in two ways in classroom discourse, namely 1) to ask if there is something existed in a page book, video or conversation text and sometimes to ask the sum of certain information existed in a textbook, 2) to tell the students something is existed or not listed in the text. The fifth one was mental process, it indicated to cognative process of learning process most. The last one was verbal process. Teachers used the verbal process in directing students to say something.

The process realized by teachers in classroom settingsfound that the lexicogrammar of the text provides indication about its context of situation. The selection of lexicogrammar of text (the transitivity system) provides the interpretation of context of situation (the field of discourse). Field refers to what is "going on", to the kind of activity that is taking place including the participants engaged in. in which the language figures as some essential component.

In short, the area of this discourse is related much to the classroom activities in schools which involves both teachers and students as the participants in the area. And the lexicogrammar realized here is related much to the process of teaching and learning English as a foreign language studied in the classroom. 


\section{Discussion}

The findings of this research indicate that classroom settings or classroom discourse has specific characteristic of lexicogrammatical unit. This phenomenon has been stated by Kress (1985) that the specific charecteristic of lexicogramatical unit which is formed from clauses, sentence and units extriccably linked to the enactment of social activities, the formation and maintanance of social identities, the interection of social groups, and the establihsment of social institutions .

The realization of material process as the first dominant process indicate that teachers as facilitator of learning in the classroom. Teachers give order, forbid students to do something, explain something, and confirm students understanding by giving question and reinforcing students if they are right or even wrong in understanding learning materials. The intention is to reach the goal of teaching learning in the classroom.

Khairunnisa (2015) said that dominant type of process in woman's text is material process. Her finding seems to be relevant with the findings of this research for all the subject are women teachers and they realized dominantly material process in interecting with the students in the classroom.

The second process frequently realized were varies, Teacher 1 and 3 share similarly that was behavioral process, while teacher 2 has her own charecteristic namely relational process. The variation occurences caused by social context. Halliday (2004) stated that perspective of systemic functional linguistics (SFL) the social context is constituted by three elements of ideology, culture and situation which are stacked up or stratified above. Teacher 1 is Bataknese, teacher 2 is Javanese and teacher 3 is Acehnese.

Amrin (2014) said that a natural object in the environment will not be automatically realized in language if the object has no relation to the needs or aspirations of the society or the social needs. In other words, natural or environmental phenomena are realized in language if the phenomena are related to culture of the speakers. The most distant element from language (ideology) is considered as the abstract factor, the nearest element to language which is directly related to language (situation) is considered as the concrete factor and the element which is in between the two factors (culture) is considered as the moderate factor of social context. Thus, the three elements of social context are realized in language as they are the properties of society. Consequently language affects the three elements as the perception of the society the implication was bataknese and acehnese teacher tend to speak directly to the action while Javanese teacher is more polite for their culture is diffrent. Sociologically speakers of language are observed as being varied or stratified in terms of their residence, welfare or prosperity, age and sex. Sociolinguistically it is said that in line with the variations or stratifications language also varies.

The processes which are realized by the teacher in classroom discourse tend to focus in transfering knowladge, to reach the goal of teaching and learning. This is almost similar with the research done by Sinar (2007). She stated that conclusively Lectur Discourse was the the 
representations of academically-oriented (rather than socially oriented) lecture activities where the focus on the transformation of intelectual values.Teacher and student realized their role and the dominant of material process is classroom discourse in formal activities.

The realization that, there are some specific verbs used to convey meanings. Those verbs related to learning process, learning interaction between teacher and students; and student to students. Those combination of processes with included the specific verbs build the classroom discourse as a unique system. It's only happened in classroom of Senior High School at X Grade with learning interaction between teacher and students. Even, in outside the classroom and learning process, those characteristic of discourse will be different. For example, when a teacher meets his/her student outside classroom with not in learning situation, then those verbs or transitivity process will be realized differently.

It is appropriate to Richards (1992:52) said that classroom discourse refers to the type of language use (parole or performance) that is found in classroom situations. It is the oral interaction that occurs between teachers and students and among students in classrooms. Through their interactions with each other. teachers and students construct a comman body knowledge, understandings of their roles and relationships.

This is relevant with Sinclair and Coulthard (1997) They stated that a three tier approach, beginning-middle-end, focused on the distinct (moves) that take place in discourese, which considered as quetion-answer-comment in the classroom environment and the norms and expectations for their involvement as member in their classrooms. One emphasizing element of field in the use of dominant material process is the fact that the classroom discourse involves formal activities.

The classroom where the research was conducted each school is one of English where the medium of instructions are both (interchangeable) English and Bahasa Indonesia (BI). In analysing data ,there was found that bahasa Indonesia has no finite concept. Sujatna (2012) said that Systemic Functional Linguistics (SFL) concerns the three metafunction meanings: clause as message, clause as exchange, and clause as representation. The clause as exchange can not be applied to Bahasa Indonesia. The word 'there' in English is equivalent to the word ' $a d a$ ' in Bahasa Indonesia. Both of the words have no representational function; they are required because of the need for a subject in English. The utterences of the teachers who speak in Bahasa indonesia is easier to analyze since it is the transitivity which ia a part of SFL.

\section{CONCLUSIONS}

The conclusions of this research are drawn as follows:

1. There were three teachers as participants in this research. Teacher 1 realized 984 clauses which dominantly realized in Material Process (339); behavioral process (213); and existential process (153). Teacher 2 realized 687 clauses which dominantly realized in Material process (258); relational 
process (118); and behavioral process (111). Teacher 3 realized 540 clauses which dominantly realized in Material process (129); behavioral process (101) and relational process (85).

2. There were 2.175 clauses realized by three teachers in two sessions for each. The type of process realized is Material process (726); behavioral process (425); relational process (296); existential process (287); mental process (250) and verbal process (191). However, the three teachers varies in the use of the process. Whereas teacher 1 and 3 share similar, teacher 2 has her own charecteristic with more process as the second ones.

3. All those processes realized in this research reflect the area of discourse as classroom areas or settings which involve communication between teachers and students in the domain of teaching and learning process.

\section{SUGGESTIONS}

In realization to the conclusions, some suggestion are staged as the following:

The teacher who has educate knowledge on experiential meaning, she/he will be able to apply in the process of teaching. It means that the communication made by the teacher more effective and the message will be easier given and understandable by the students. The teachers should have better social competence as an indicator of professional teachers. It is suggested that the teachers should have better social competence by which she can be professionalism of teachers.

English teachers should give more chance for students to realize more clauses as to increase their activeness in using English as a foreign language they learn. It is due to the fact that in the classroom settings teachers realized more clauses than the students. It is suggested that further studies should be done on classroom discourse from the perspective of its personal function.Mood is also advised to studies

Further studied should be expanded on transitivity with diffrent varies such as related to interpersonal matters.

\section{REFERENCES}

Bogdan, RC. 1992. Qualitative Research forEducation: An Introduction to Theory and Methods(2nd $E d$.$) . Boston. : Allyn and Bacon$

Coulthard, M. 1997. An Introduction to Discourse Analysis, Longman, England, pp 93-115.

Eggins, S, 1994. An Introduction to Systemic Functional Linguistics. London:Continuum.

Eggins, S. 2004. An Introduction to Systemic Functional Linguistics, (2nd ed.)London: Printer Publisher.Ellis, R. 1994 The Study of Second Language Acquisition. Oxford: Oxford University Press. 
Halliday, M. A. K. 1985. An Introduction to Functional Grammar. London: Edward Arnold.

Halliday, M. A. K. 1994. An Introduction to Functional Grammar (2nd Ed.). London: Edward Arnold.

Halliday, M.A.K.\&Mathieson, C.M.I.M. 2004. An Introduction to Functional Grammar. London: Arnold.

Halliday, M.A.K. 2014. An Introduction To Functional Grammar, Third Edition, Introduction. Edited by Jonathan Webster. London and New York: Continuum.

Khairunnisah . 2015. The Experiential Function Used by Men and Women in Writing Opinion at www.kompasiana.com. English AppliedLinuistics. Post Graduate Program State University of Medan UNIMED.Thesis.

Kress, G. 1985. Ideological Structures in Discourse, in VanDijk, T.A, Handbook of Discourse Analysis, Vol.4, Academic Press Inc, (London) Ltd., London, pp. 27-42 , (online, 14 April 2016).

Richards, J.C. et al. 1992 A Dictionary of Applied Linguistics. London: Longman.

Saragih A, 2014 Variations And Functional Varieties of Language, English Department Faculty of Arts and Languages the State University of Medan.

Sibarani B. 2004. Qualitative Research in Linguistics and Language Teaching: Course Materials for Graduate Students of English Applied Linguistics. Medan: Graduate Program State University of Medan.

Sinar, ST. 2007. Phasal and Experiential Realizations in Lecture Discourse. Medan. :Kopertis Wilayah I SUMUT-NAD.

Sinclair, J. M. \&Coulthard, R.M. 1975. Towards an Analysis of Discourse: the English Used by Teachers and Pupils. London: Oxford University Press

Sujatna ETS, 2012, International Journal of Linguistics, (online) ISSN 1948-5425, 2012, Vol. 4, No. 2 (online 12 april 2016). 